\title{
Control of acariosis in Helix aspersa Müller in production farms
}

\author{
Yuste $\mathrm{A}^{1}$, Calvo $\mathrm{A}^{2}$, Marcelo JA ${ }^{2}$, Arosemena $\mathrm{EL}^{1}$, Nogué $\mathrm{E}^{1}$ and Calvo MA ${ }^{1 *}$ \\ ${ }^{1}$ Grupo de Investigación en Microbiología Aplicada y Medioambiental, Facultad de Veterinaria. Universidad Autónoma de Barcelona. Cerdanyola del Vallés, \\ Barcelona, Spain \\ ${ }^{2}$ Granja Cal Jep, Castellfollit del Bosc, Barcelona, Spain
}

\begin{abstract}
Helix aspersa Müller is the land snail most consumed by humans. Among the health alterations that snails present, it is cited, the acariosis caused by the parasite Riccardoella limacum (Schrank, 1776), that can trigger in a high percentage of cases, the death of the snail. The present study provides an assessment of the capacity of two ecological products: oxalic acid and thymol to combat this pathology.
\end{abstract}

\section{Introduction}

Heliciculture is a term that comes from Latin and defines a productive process by which edible land snails are raised in captivity [1].

There are different species that are included within the group of land snails, Helix aspersa Müller being one of the most important, as it is preferentially consumed in Catalonia. The snail is a gastropod mollusc of mainly Mediterranean origin that belongs to the family Helicidae [2].

From an anthropological point of view, land snails can have benefits and harms [2]. The beneficial aspects are mainly based on their production as farm animals, destined for consumption, as well as their use as experimental animals since it is considered a good biological indicator [3]. Conversely, they are also related to pests that can cause serious losses in agriculture and, in addition, several species of snails are intermediaries of parasites that can affect humans [2].

It has been confirmed that the consumption of snail meat is beneficial to human health, mainly as a result of its low level of lipids, the great variety of mineral salts it contains, especially iron and calcium, and that its consumption determines a comparatively low caloric contribution, as can be seen in the Table 1 and Figure $1[1,4]$.

Land snails grow well in an environment where temperature conditions range from $18^{\circ} \mathrm{C}$ to $20^{\circ} \mathrm{C}$ and humidity from 70 to $80 \%$. A
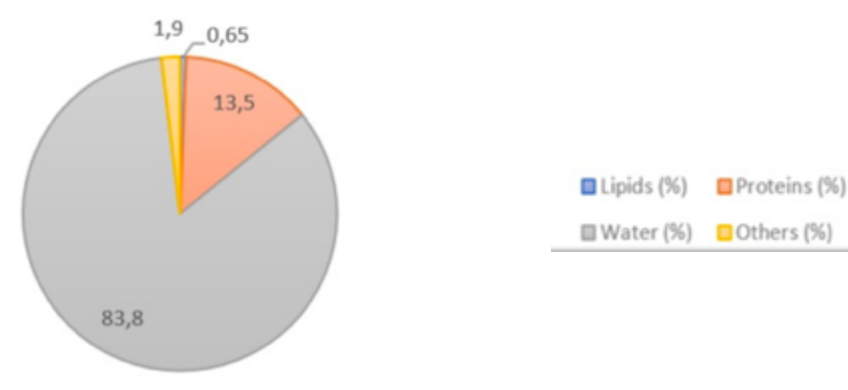
aWater (\%) aOthers (\%)

Figure 1. Composition of snail meat [4].
Table 1. Comparative table of the composition of different foods [1]

\begin{tabular}{|c|c|c|c|c|}
\hline Food & Water & Proteins & Lipids & Calories \\
\hline Beef meat & 62,8 & 18,8 & 15,4 & 214 \\
Chicken & 68,7 & 19,1 & 11,9 & 175 \\
Egg & 73,9 & 13,0 & 11,2 & 156 \\
Fish & 81,5 & 15,9 & 2,6 & 82 \\
Snail & 84,9 & 13,4 & 1,7 & 67 \\
\hline
\end{tabular}

higher percentage of humidity can cause pathologies of fungal etiology $[1,5]$.

As in the rest of the animal species, the stability of the microbiota in snails is very important because it participates in their welfare by contributing to their immune response and metabolism, but this microbiota is not stable because it shows a marked dynamism, a consequence of its evolution over time caused by different factors, among which are the age of the snail, the type of food and environmental conditions [6,7].

The normal microbiota of these animals consists mainly of species of the genus Lactobacillus, Lactococcus and Pediococcus, among the bacteria, and of Candida and Cryptococcus among the major genus of yeast $[8,9]$.

It should be noted that when enteropathogenic symptoms are present on snail farms, a marked reduction in the presence of lactic acid bacteria is simultaneously observed in contrast to the notable increase in strains of species belonging to the Enterobacteriaceae family, with a particular increase in strains of Escherichia, Klebsiella, Enterobacter and Citrobacter $[8,9]$.

*Correspondence to: $\mathrm{M}$. Angeles Calvo, $\mathrm{PhD}$, Grupo de Investigación en Microbiología Aplicada y Medioambiental, Facultad de Veterinaria. Universidad Autónoma de Barcelona. Cerdanyola del Vallés, Barcelona, Spain, E-mail: MariAngels.Calvo@uab.cat

Key words: Helix aspersa Müller, heliciculture, acariosis

Received: April 03, 2020; Accepted: April 24, 2020; Published: April 29, 2020 
Although it may also be affected by other pathologies caused by different microorganisms, the main one being the presence of Pseudomonas aeruginosa, which can cause high mortality; the infection caused by strains of the genus Listeria and Clostridium, among others, is also cited $[8,9]$.

The filamentous fungi and the yeasts are also etiological agents of processes of infection in snails and between the most out-standing genus we can mention: Rhizopus, Geotrichum, Aspergillus and Fusarium among the mycelial fungi and Rhodotorula and Candida, among the yeasts $[8,9]$.

Snails can also be affected by parasites, including Riccardoella limacum (Schrank, 1776), which causes one of the most serious snail diseases known as acariosis [10].

Riccardoella limacum acts as an ectoparasite by feeding on the blood of its host's respiratory tissue, causing a reduction in growth rates and activity and leading to the death of the animal [8]. Furthermore, it has been shown that transmission of this mite occurs very easily between animals and, between environment and animals and also indirectly through the user's clothing and utensils (feeders and drinkers) [10-12].

It is a small whitish parasite belonging to the Ereynetidae family, also called "slug mite"; it is approximately $0.3 \mathrm{~mm}$ long, feeds on the blood of the snail and is located in the paleal cavity or lung, an area irrigated by a large number of blood capillaries [11,12].

Riccardoella limacum does not remain permanently anchored to the parasitic snail because it moves freely in its palatal cavity and on its external surface, attaching itself to the blood capillaries only to feed [11].

It's a parasite with only host, the snail, which complicates its fight very much. Its biological cycle follows the sequence: egg - larva - "3 nymphs" - adult (Figure 2) [11].

It parasitizes all snails, both wild and intensively farmed. In the open snail state, Riccardoella limacum is laid in spring and summer, when environmental conditions are ideal; while in controlled environment farms, the female mite lays eggs throughout the year, resulting in a large increase in parasitation [11,12].

Acariosis is transmitted slowly but progressively. When snails have a slight parasitation ( $<10 \mathrm{mites} / \mathrm{snail})$, it can be detected by observing

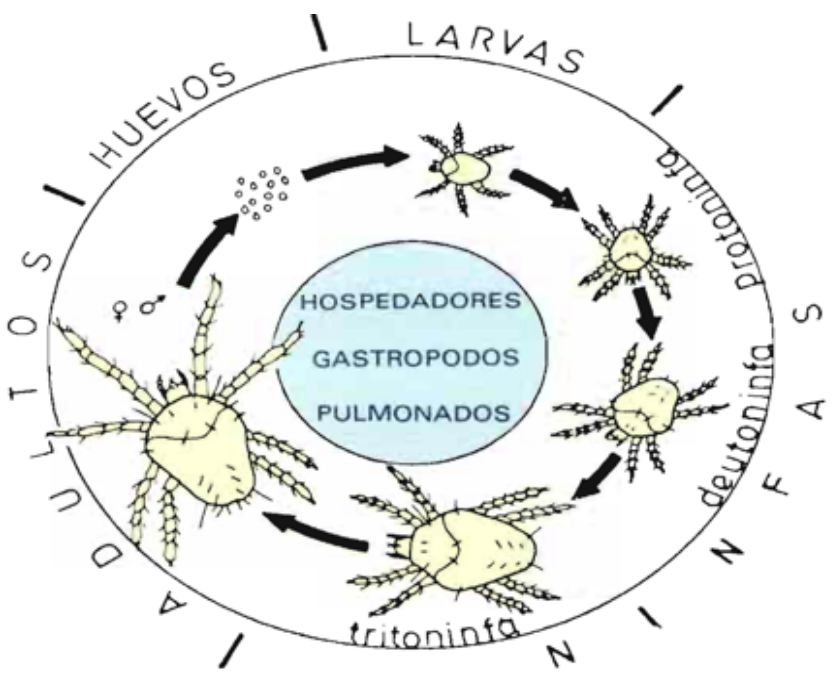

Figure 2. Riccardoella limacum life cycle [11] the snail when it is introduced into its shell: small white spots are seen moving on its surface. As the degree of parasitation increases, the number of clutches decreases, the number of eggs per clutch decreases and the animal progressively stops eating $[11,12]$.

A high concentration of parasites in the paleal cavity (>100 mites/ snail) leads to an $80 \%$ reduction in the farm's helicopter population, due to the strong anemic processes for which mites are responsible. The remaining $20 \%$ of snails will progressively die within a few months [10].

The aim of this study is to evaluate the effects of environmentally friendly products that can combat acariosis without affecting the snail and to confirm that these compounds do not affect the lactic acid bacteria that form part of its microbiota and that are added as probiotics to the feed.

\section{Material and methods}

The parasitized snails were provided by a production farm and different fattening farms, located in the province of Barcelona (Catalonia). The snails were transferred to the laboratory of Applied and Environmental Microbiology of the Veterinary Faculty of the Autonomous University of Barcelona, under refrigeration conditions.

The feed for the animals is formulated and prepared by a factory specialized in the production of feed in the province of Barcelona (Catalonia) and is stored correctly to be transported to the laboratory of Applied and Environmental Microbiology of the Faculty of Veterinary Medicine of the Autonomous University of Barcelona.

The products selected to evaluate their effect against acariosis were oxalic acid and thymol. These compounds are mixed with the feed and consequently it is also evaluated if their addition can determine a change in the organoleptic characteristics of the feed that causes the animals to stop feeding.

Different concentrations of oxalic acid and thymol were tested in order to determine the optimal dose that would facilitate the elimination of the parasite without altering the organoleptic characteristics of the feed and the presence of the added probiotics in the feed.

The tested concentrations are summarized in Table 2. Observation of the snails makes it possible to determine the presence or absence of parasites and also whether they stop feeding or not.

The possible effect on the concentration of probiotics is made by microbiological analysis of the feed enriched with the probiotic and added to the mixture that provides a better result. The microbiological analysis is carried out by counting the probiotic, added to the feed, expressed as Colony Forming Units per gram of feed (CFU/g) on Man Rogosa Sharpe Agar (MRS). (Ref: BK089HA, Biokar diagnostics ${ }^{\oplus}$, France) weekly for one month.

\section{Results}

The presence of the parasite is confirmed macroscopically and with a binocular magnifying glass (Figure 3 ).

By adding to different feed lots, the mixtures indicated in Table 3 and maintaining lots to which no acaricide was added as controls, it has been possible to determine that the concentration from which the parasites were no longer observed and did not affect the organoleptic characteristics of the feed is that which constitutes Mixture 2, consisting of: $0.04 \%$ Thymol and $0.3 \%$ oxalic acid.

All the counts of probiotics in the feed, both the control and the mixture, were made in the $1 / 1000$ dilution since it is the one that allows 
Table 2. Tested concentrations of each product

\begin{tabular}{|c|c|c|c|c|}
\hline Products & Control & Mix 1 & Mix 2 & Mix 3 \\
\hline Thymol & $0.0 \%$ & $0.03 \%$ & $0.04 \%$ & $0.05 \%$ \\
\hline Oxalic acid & $0.0 \%$ & $0.2 \%$ & $0.3 \%$ & $0.4 \%$ \\
\hline
\end{tabular}

Table 3. Log values of feed $\mathrm{CFU} / \mathrm{g}$ and different statistical values such as average and standard deviation

\begin{tabular}{|c|c|c|c|c|}
\hline Feed + Probiotic & $\mathbf{1}^{\text {st }}$ week & $\mathbf{2}^{\text {nd }}$ week & $\mathbf{3}^{\text {rd }}$ week & $\mathbf{4}^{\text {th }}$ week \\
\hline $\begin{array}{c}\text { Feed + Probiotic } \\
+\begin{array}{c}\text { Oxalic acid + } \\
\text { Thymol }\end{array}\end{array}$ & 6,87 & 6,51 & 6,17 & 5,94 \\
\hline Average & 6,805 & 6,49 & 6,11 & 5,81 \\
\hline $\begin{array}{c}\text { Standard } \\
\text { deviation }\end{array}$ & 0,09192388 & 0,01414214 & 0,04242641 & 0,09192388 \\
\hline $\begin{array}{c}\text { Number of } \\
\text { variables }\end{array}$ & 2 & 2 & 2 & 2 \\
\hline Standard error & 0,065 & 0,01 & 0,03 & 0,065 \\
\hline
\end{tabular}

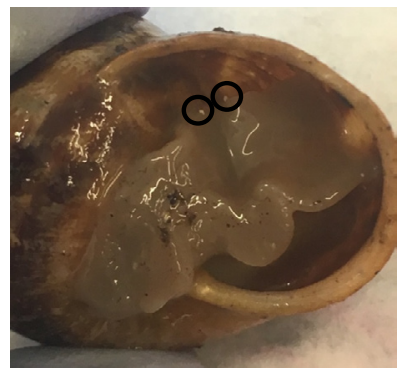

(A)

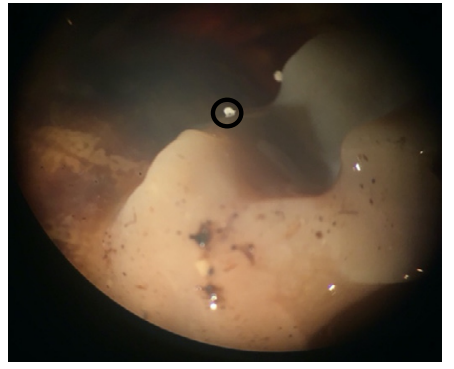

(B)
Figure 3. (A) Macroscopic view of the parasites; (B) Image under binocular magnifying glass of parasites

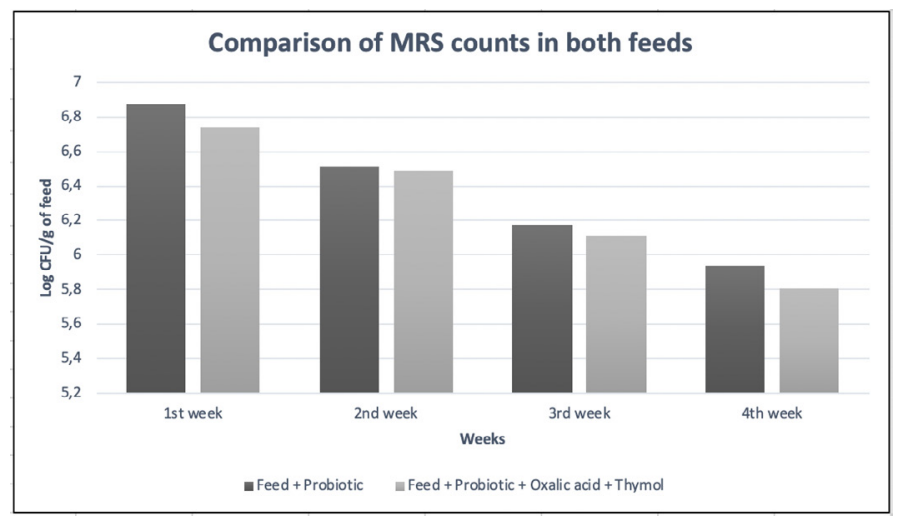

Figure 4. Comparison of MRS plate counts in both feeds over four weeks a better count. As can be seen in Table 3 and Figure 4, a decreasing evolution of the count is detected in both cases because there is a loss of these bacteria.

\section{Discussion}

The data in Table 2 indicates that the deviation and the standard error are very low and, therefore, this indicates that the variation of CFU/g between both feeds is minimal and consequently the addition of $0.04 \%$ Thymol and $0.3 \%$ oxalic acid does not cause a significant decrease in lactic acid bacteria compared to the non-acaricide feed.

Considering the results provided, it can be concluded that the addition of $0.04 \%$ thymol and $0.3 \%$ oxalic acid to the feed prepared for farm snails, allows the fight against acariosis and is not harmful to the snail or to the probiotic strain added to the feed.

\section{References}

1. Pereyra RL, Maiorano L, Raimondi N, Ybalo C (2003) La Helicicultura. Invenio 6 : 127-134.

2. Olivares CA (2005) Caracterización de algunos aspectos biológicos básicos del caracol de tierra Helix aspersa (Mollusca: Gastropoda: Stylommatophora) en la IV región de Chile. Biociencias 13: 177-192.

3. Perea J, Martín R, Acero R, Goméz F, García-Mayoral AM, et al. (2006) Selección de habitat en caracoles terrestres y sus aplicaciones a la helicicultura. Archivos de Zootecnia 55: 1-12.

4. Conte R (2015) Heliciculture: purpose and economic perspectives in the European community. The Official Journal of the Institute of Science \& Technology.

5. Iglesias J, Castillejo J (1999) Field observations on feeding of the land snail Helix aspersa Müller. Journal of Molluscan Studies 65: 411-423.

6. González-Núñez C, Calvo-Torras MA (2015) Comparison of the microbiota of snails (Helix aspersa) of different weights and its evolution over time. Journal of Veterinary Science \& Technology 6: 1-3.

7. Pérez L, Girmé G, Arosemena EL, Calvo A, Marcelo JA, Calvo MA (2014) Microbiota from Helix aspersa Müller in Barcelona Area (Spain). Advances in Microbiology 4: 604-608.

8. Vera RE (2016) Microbiología del caracol Helix aspersa Müller. Aplicaciones biotecnológicas para su mejoramiento sanitario con impacto en su comercialización. Ph.D. Dissertation, Universitat Autònoma de Barcelona, Bellaterra.

9. Kiebre-Toe MB, Borges E, Maurin F, Richard Y, Kodjo A (2003) Etude de la flore bactérienne aérobie à Gram négatif de l'escargot d'élevage (Helix aspersa). Revue de Médecine Vétérinaire 154: 605-610.

10. Schüpbach HU, Baur B (2008) Experimental evidence for a new transmission route in a parasitic mite and its mucus-dependent orientation towards the host snail. Parasitology 135: 1679-1684. [Crossref]

11. Fontanillas JC (1988) La acariosis, una grave enfermedad de los caracoles. Ministerio de Agricultura, Pesca y Alimentación.

12. Caracoles, Acariosis, Helicicultura: Patlogía parasitaria en caracoles, Riccardoella limacum - Examen microscópico (2020). Recuperado de https://www.ivami.com/es/ microbiologia-veterinaria-molecular/2185-caracoles-acariosis-helicicultura-patologia-parasitaria-en-caracoles-riccardoella-limacum-examen-microscopico.

Copyright: (C2020 Yuste A. This is an open-access article distributed under the terms of the Creative Commons Attribution License, which permits unrestricted use, distribution, and reproduction in any medium, provided the original author and source are credited. 